\title{
ENSINO JURÍDICO: CRÍTICA E PERSPECTIVAS
}

\section{LEGAL EDUCATION: CRITICISM AND PROSPECTS}

\section{EVELISE SLONGO DUDZIAK}

Mestranda em Direito Empresarial e Cidadania - Centro Universitário Curitiba UNICURITIBA. Curitiba - PR. E-mail: evelise.gu@gmail.com

\section{Fábio André GUARAGNI}

Professor Coorientador - Centro Universitário Curitiba - UNICURITIBA. Curitiba - PR. E-mail: guaragni@mppr.mp.br.

\section{RESUMO}

A discussão sobre a educação desde sempre esteve em voga entre os pedagogos, docentes e epistemólogos, mas atualmente, a sociedade parece estar um tanto mais envolvida com o tema, principalmente após tantas mudanças advindas da política nacional, desde a criação das provas de qualificação de escolas e faculdades, bem como, após a multiplicação dos cursos de graduação como o de Direito. A discussão ganha maiores contornos, ao nos depararmos com a maneira com que os estudantes do curso de Direito saem dos bancos da academia. Percebe-se a nítida falha na formação desses indivíduos, pois naquele meio acadêmico o que existe é a mera formação de técnicos. Diante dessa evidência, pretendeu-se diagnosticar os problemas e apontar prováveis caminhos a serem construídos e aprimorados. Para tanto, utilizou-se do método dedutivo, partindo-se de uma análise geral das falhas do ensino jurídico, passando pelas exigências da sociedade atual, até adentrar na temática principal que é o tracejamento de opções a serem seguidas, apontando ideias de superação da atual realidade. Restou comprovada a importância da 


\section{Personalidade Acadêmica Homenageada:}

Augustus B. Cochran III (Agnes Scott College)

interdisciplinaridade para uma formação mais completa. Os cursos de Direito têm se mostrado distantes da realidade social, econômica e filosófica. Fechados demais, percorrendo tão somente a técnica jurídica. "No particular da questão da postura reflexiva e de visão crítica, chama-se atenção para o distanciamento entre teoria e prática e para o isolamento das disciplinas". (WIVIURKA e SOUZA, 2011, p. 154). Através da interdisciplinaridade é que se pretende fugir da regra da mera instrumentalidade. O Direito não merece ser simplificado, reduzido a instrumento. "Se o direito fechar-se a si mesmo, terminará por não conhecer seus fenômenos e continuará a dar soluções pouco satisfatórias para as demandas sociais." (WIVIURCA e SOUZA, 2011, p. 155). O ensino jurídico deve buscar praticidade, ou seja, "embora direito seja linguagem, portanto, texto, este texto é sempre um evento. Não se interpreta em abstrato. Por isso a tese hermenêutica da applicatio. Por isso, a hermenêutica é facticidade; não é método: é filosofia, é condição de ser no mundo."(STRECK, 2007, p.29). Ademais, deve-se buscar um aprendizado reflexivo, longe das velhas práticas, redundantes em infinitas leituras, em linguagem difícil. Deve-se guiar o estudo do Direito por um caminho mais próximo da pesquisa e longe de manuais arcaicos, de duvidosa cientificidade. O extremo positivismo deve ser abandonado. Para a construção de um novo ensino do Direito, necessário se faz também uma mudança no papel dos professores, que passam de ministradores de aulas expositivas a verdadeiros mediadores pedagógicos entre aluno e conteúdo, através de uma relação de parceria e corresponsabilidade. Tal postura, acaba por modificar também o aluno, que mais motivado, passa a ser também corresponsável pelo seu próprio aprendizado (MASETTO e TAVARES, 2013, p.41). Por certo que não se encontra facilmente professores com as características apropriadas, ou preparados para debates e discussões, por isso não bastam currículos inovadores nas Universidades. Necessita-se de mais aprimoramento ao se selecionar os docentes, bem como é necessário o desenvolvimento de um contínuo aprimoramento de métodos, uma espécie de formação continuada de docentes. (MASETTO e TAVARES, 2013, p. 44). As críticas às aulas expositivas não podem ser abandonadas diante de um sentimento de impotência, tais críticas merecem ser consideradas para se pensar um novo padrão de ensino jurídico. Desta forma, a mudança de perspectiva 
Personalidade Acadêmica Homenageada:

Augustus B. Cochran III (Agnes Scott College)

de ensino merece ser levada a sério. A crise atual da educação é decorrente de uma estruturação mal desenvolvida com início já no ensino fundamental, que pode e deve ser corrigida também nos bancos universitários, longe de modismos e ideologias, de modo a formar pessoas conscientes, críticas e, portanto, aptas a desenvolver com sabedoria seu ofício.

PALAVRAS-CHAVE: Ensino-jurídico; Crítica; Interdisciplinaridade.

\section{REFERÊNCIAS}

MASETTO, Marcos Tarciso e TAVARES, Cristina Zukowsky. Inovação e a Universidade. José Garcez Ghirardi e Marina Feferbaum (Org). Ensino do direito em debate: reflexões a partir do $1^{\circ}$ Seminário Jurídico e Formação Docente. São Paulo: Direito GV, 2013, (p. 33-46). Disponível em: http://bibliotecadigital.fgv.br/dspace/bitstream/handle/10438/11274/Ensino\%20do\%2 0direito\%20em\%20debate.pdf?sequence=1 . Acesso em: 04. jun.2019.

STRECK, Lenio Luiz. Hermenêutica e ensino jurídico em Terrae Brasilis. Revista da faculdade de Direito da UFPR, v.46, 2007. Disponível em: https://revistas.ufpr.br/direito/article/view/13495/9508 . Acesso em: 30.mai.2019.

WIVIURKA, Eduardo Seino e SOUZA, Emanoel Dall'Agnol de. Perspectivas de transformação do ensino jurídico: A postura reflexiva e crítica na pedagogia progressista. Revista Jurídica UNICURITIBA, v.26, n.10. UNICURITIBA: Curitiba, 2011.

em http://revista.unicuritiba.edu.br/index.php/RevJur/article/view/178. Acesso em: 28.mai.2019. 